\title{
Some Recent Decisions on the Law of Taxation"
}

$\mathrm{O}^{\mathrm{x}}$ recent years the pressure of increasing taxation has been a familiar political and economic phenomenon. In the field of the law the changes which have been taking place have been correspondingly reflected, until today the subject has become one of outstanding importance to the legal practitioner as well as to the theorist. This development is illustrated in an interesting fashion in the work of the Supreme Court of the United States. Going back to its 1910 term, for example, of all cases decided in which opinions were written, approximately $9 \%$ involved questions of taxation. At the 1920 term about $15 \%$ related to this topic. Within the last dozen years this percentage has doubled, and during the 1932 term $31 \%$ of all the Court's opimions involved tax problems.

The lower federal courts and the state courts also have been increasingly concerned with matters of taxation. The result is a welter of decisions during the course of a year. To review these decisions is a large undertaking. Obviously it is impossible in a single paper to mention more than a small proportion of the total. All that can be done is to select a few which appear to be of the greater interest or importance. Most of those chosen will be cases decided by the United States Supreme Court. The period covered will be, in general, that of its last term-in other words, the year beginning October, 1932.

In surveying the output of the courts during this period, one is inipressed more by its mass than by novelty or unusual change. There is nothing comparable, for instance, to the revolutionary developments of the preceding few years with respect to the jurisdiction of the states to tax intangibles; nor comparable to the developnent over a slightly earlier period of the subject of constitutional limitations upon state franchise taxation. Speaking of jurisdiction, however, there is one decision which calls for mention, and it will afford a convenient starting point.

\section{JURISDICTION}

The case of the year on this subject is Burnet v. Brooks. ${ }^{1}$ It involved the levy of a federal estate tax upon the succession to certain property of an intangible nature belonging to a non-resident alien. The property consisted principally of securities, including bonds of foreign

* This paper was presented at the annual conference of the National Tax Association, held in Phoenix, Arizona, Oct. 16-20, 1933.

1 (1933) 288 U. S. 378. 
governments and corporations, bonds of domestic corporations, and stock in a foreign corporation. The bonds and stock certificates were in the possession of agents within the United States. As a matter of statutory construction the Supreme Court held that the property was "situated in the United States" within the language of the Revenue Act and hence taxable according to its terms. ${ }^{2}$ The question then arose whether the tax was constitutional. It is apparent that the only basis of jurisdiction lay in the physical presence of the securities in this country, plus, in the case of the domestic obligations, the local domicile of the debtor corporations. It is also apparent under the recent and familiar decisions of the Supreme Court with respect to state taxation, ${ }^{3}$ that no state could levy an inheritance tax upon the property. For state purposes the only taxable situs would be at the domicile of the owner. The issue thus was whether the limitations imposed upon the states by the due process clause of the Fourteenth Amendment apply also to the federal government under the due process clause of the Fifth Amendment. The Court held not. This result was foreshadowed by earlier decisions, ${ }^{4}$ but these antedated the late cases as to state taxation and were decided at a time when there was strong authority to support even a state tax upon the property in question. Hence prior to the decision now under discussion it had been regarded as doubtful whether a federal tax would be deemed constitutional under such circumstances as these. Burnet v. Brooks is important in removing this doubt and making clear that the jurisdiction of the federal government to tax is not subject to the limitations which have been imposed upon the states. The Court approached the issue from the point of view of international law, and poimted out that so far as international relations were concerned, ample justification for the exercise of jurisdiction was present. ${ }^{5}$

\section{Classification and UNIFORMITY}

Another fundamental constitutional limitation consists in the requirement of uniformity of taxation. This is imposed by the equal

2 Revenue Act of 1924, \$303, 43, STAT. (1924) 305, 26 U. S. C. (1926) $\$ 1095$.

3 Farmers Loan \& Trust Co. v. Minnesota (1930) 280 U. S. 204; Baldwin v. Missouri (1930) 281 U. S. 586; Beidler v. South Carolina Tax Comm. (1930) 282 U. S. 1; First National Bank v. Maine (1932) 284 U. S. 312.

The Supreme Court has refused to review on certiorari a decision of the circuit court of appeals to the effect that the state of a debtor's domicile does not have jurisdiction to levy an income tax on interest paid by such debtor outside the state to non-resident creditors. Domenech v. United Porto Rican Sugar Co. (C. C. A. 1st, 1932) 62 F. (2d) 552, cert. den., (1933) 289 U. S. 739.

4 United States v. Bennett (1914) 232 U. S. 299; DeGanay v. Lederer (1919) 250 U. S. 376.

5 For somewhat contrasting points of view on this case, see (1933) 33 Cor. L. REv. 925; (1933) 42 YALE L. J. 1277. 
protection clause of the Fourteenth Amendment to the federal Constitution, as well as by specific provisions in various state constitutions. On this topic there have been several noteworthy decisions.

In Williams v. City of Baltimore, ${ }^{6}$ the United States Supreme Court had before it the question of the constitutionality of a Maryland statute which exempted from taxation for two years the property of a specific railroad-the Washington, Baltimore and Annapolis Electric Railroad Co. The case came up from the federal circuit court of appeals, which had held the statute unconstitutional. ${ }^{7}$ In its opinion the circuit court had followed the routine line of argument that while the Constitution permits the classification of property for the purpose of taxation, such classification must be reasonable, not arbitrary, and all persons similarly circumstanced must be treated alike. Here, it said, there was no classification, but an arbitrary exemption was granted to a single taxpayer. Even the further fact that the favored railroad was insolvent was not regarded as sufficient to alleviate the difficulty, since, in order to have a proper classification, the exemption should at least have been extended to other insolvent railroads. This holding was reversed by the Supreme Court. For reasons not of present interest, the Court did not consider the federal Constitution at all, but decided the case under the umiformity clause of the state constitution. There is no reason, however, to believe that the same result would not have been reached under either constitution. Making a realistic approach to the problem, the Court viewed the situation not as a type, but in the light of its factual background. The exempted railroad did a large passenger business, supplying the only rail service between Baltimore and Annapolis, the capital of the state. Large public interests were involved in keeping its service going. Circumstances were present here which would fairly justify the legislature in treating this as a special case. Fornal classification is unnecessary and an individual exemption is not arbitrary, when from the point of view of the public interest the case presents an individual problem. To quote the Court:

"The public policy that made it wise in the judgment of the legislature to lielp this particular railroad and keep its business going may have failed altogetler in respect of any other railroad, solvent or insolvent. Here was a line carrying millions of passengers, and supplying the only railroad service between the capital of the state and its most populous city. The rescue of such a road miglit be dictated by the public interest when a road in some other territory miglit wisely be abandoned to its fate." 8

The opinion, written by Mr. Justice Cardozo, is worthy of unore

6 (1933) 289 U. S. 36.

7 (C. C. A. 4th, 1932) 61 F. (2d) 374.

${ }^{8}$ Supra note 6, at $42-43$. 
than usual notice for its realistic treatment of the issues and for its willingness to look beyond the statement of abstract rules, to consider the practical workings of the legislation under attack.

This unanimous opinion in Williams v. City of Baltimore may be contrasted with the decision of the majority of the Supreme Court in another case, involving the troublesome problem of excise taxes on chain stores. That some discrimination against such stores is constitutional was established in 1931, when the Court in State Board of Tax Commissioners $v$. Jackson ${ }^{9}$ upheld by a five-to-four vote an Indiana statute which imposed a license fee on all stores, the amount of the fee being graduated according to the number operated under the same management or ownership within the state. It was felt that the differences between chain stores and those operated as individual units consisted not merely in ownership, but in organization, management and type of business transacted, and that these differences were sufficient to constitute a reasonable basis of classification. This year, in Liggett Co. v. Lee, ${ }^{10}$ the Court had to determine the constitutionality of a Florida statute which likewise imposed a tax on stores graduated according to the number operated. So far as the general principle of graduation was concerned, the Court reaffirmed the holding of the Jackson case. But the Florida statute involved an important additional feature-the amount of the fee per unit was dependent not merely on the number of stores operated within the state, but also upon whether these were located exclusively in one county or in more than one county. Where all the stores were in one county, the tax per unit was less than if the same number of stores were located in several counties. The critical question was whether any reasonable basis for classification could be found in this matter of county location. By a six-to-three vote the Court held not. The majority stated that an increase in the levy not only on a new store but on all the old stores, consequent upon the mere physical fact that the new one lay a few feet over a county line, found no foundation in reason or in any fact of business experience. It was said further that the adoption of a county line could have no reference either to density of population, congregation of the buying public, or any other factor bearing upon the choice of a business site.

This view was opposed in a dissenting opinion by Mr. Justice Cardozo. He pointed out the classification used by the Census Bureau, according to which chain stores are divided into three groups: local, sectional and national. He then stated that there was a definite line of cleavage between local chains on the one hand and sectional and 
national chains on the other, based upon substantial differences both in the business itself and in its effect upon the social organism; that these differences afforded a reasonable basis for classification, and hence that the legislature was justified in drawing a line between local chains and others. But where does the local have an end and the nonlocal a beginning? It was necessary to draw the line somewhere, and in drawing it with the county the legislature, he said, acted within the bounds of reasonable discretion. In this connection he pointed out that in Florida the county is the distinctive unit of government, and that the boundaries of the county will have an approximate correspondence with the area of local business. When a chain goes beyond the county, beyond the traditional boundaries of local government, it puts the locality behind it, and elects to play for larger stakes.

This point of view has a good deal of plausibility, and it is evident that the merits of the Liggett case leave ample room for debate. ${ }^{11}$ It may be noticed that the difference in the results reached in the Indiana and Florida cases was due to the votes of two judges-Mr. Chief Justice Hughes and Mr. Justice Roberts (the latter of whom wrote the majority opinions in both cases). Of the other seven judges, four voted to hold both statutes unconstitutional, while the other three voted in each instance in favor of constitutionality. Mention should also be made of the elaborate dissenting opinion of Mr. Justice Brandeis, who took a more extreme position than that of $\mathrm{Mr}$. Justice Cardozo. ${ }^{12} \mathrm{He}$ stressed the social and economic purpose of the statute, which presumably was intended to discourage the operation of the large corporate chain stores. This he thought was sufficient to justify the legislation. In this connection he reviewed the historical development of big corporations in the Umited States and of their legal position.

As illustrative of the normal freedoin which the legislatures possess in classifying for tax purposes, reference may be made to Broad River Power Co. v. Query. ${ }^{13}$ A South Carolina statute imposed an excise on the production and sale of electric power. Clain was made that the statute denied the equal protection of the laws, contrary to the Fourteenth Amendment, in that the tax was laid upon the production of electricity by water power or steam power, while generation by the use of oil or internal combustion engines was not taxed. But the Supreme Court had no difficulty in finding a reasonable basis for this classification.

11 Comment in the law reviews favors the dissenting view. See (1933) 33 CoL. L. Rev. 754; (1932) 46 Harv. L. Rev. 155; (1933) 28 IrL. L. Rev. 288; (1933) U. OF PA. L. REv. 871.

12 For a statement of the position taken by $\mathrm{Mr}$. Justice Brandeis and comment thereon, see (1933) 28 ILL. L. REv. 288.

13 (1933) 288 U. S. 178. 
Sometimes the state legislatures are more restricted by uniformity clauses and similar provisions in state constitutions than by the federal Constitution. This is illustrated by the fate of graduated incone tax laws, which often have been overthrown because of local constitutional provisions. The prevailing conflict of authority on this question has been continued during the past year. Incone tax acts have been held unconstitutional in Illinois and Tennessee, ${ }^{14}$ but sustained as constitutional in Missouri and Idaho. ${ }^{15}$

\section{The Taxation of Banks}

Of recent years nuch litigation has been caused by the attenipts of the states to collect taxes from national banks-attempts which so frequently have run afoul of section 5219 of the Revised Statutes of the United States. ${ }^{16}$ This year the more interesting decisions have been concerned not so much with the application of that section as with collateral questions which have arisen out of the invalidation of state tax legislation because of conflict therewith.

In Union Bank \& Trust Co. v. Phelps, ${ }^{17}$ the complaining taxpayer was a state bank in Alabania. The state statutes liad provided for the levy of a uniform ad valorem tax upon the shares of all banks, both state and national. But in spite of the statute the national bank shares had wholly escaped, for the reason that certain competing noneyed capital was exempt froin ad valorem taxation under the Alabama law. Hence it had been held that under section 5219 no such taxes could be collected with respect to the national banks. Shares in the state banks, lowever, continued to be taxed in accordance with the statute, and it was contended by such banks that to tax their shares while national bank shares were not taxed, was a denial of the equal protection of the laws. The Court rejected this contention, holding that the very fact that the national banks are a federal instrumentality is sufficient to justify placing them in a separate class. Nor do shares of national and state banks become essentially the same nerely because the state has attempted to subject them to hike treatment. It was also held not to be a demial of the equal protection of the laws to tax the state bank shares, while other competing capital, such as the property and shares of building and loan associations, industrial loan corporations, industrial banks, inortgage conpanies, etc., was exempted.

14 Bachrach v. Nelson (1932) 349 Ill. 579, 182 N 2 E. 909; Evans v. McCabe (1932) 164 Tenn. 672, 52 S. W. (2d) 159, 617. See (1932) 46 Harv. L. REv. 339.

15 Diefendorf v. Gallet (1932) 51 Idaho 619, 10 P. (2d) 307; Bacon v. Ranson (Mo. 1932) 56 S. W. (2d) 786.

1642 STAT. (1923) 1499,12 U. S. C. (1926) $\$ 548$.

17 (1933) 288 U. S. 181. 
In First National Bank v. Louisiana Tax Comm., ${ }^{18}$ arguments similar to those just discussed were again presented, but this time on behalf of certain national banks. The latter first attempted to evade state taxes upon their shares under section 5219 of the Revised Statutes, but this attempt failed because, although other moneyed capital was escaping taxation, wholly or in part, it was not definitely proved that such capital was actually coming into competition with the business of the national banks. The point is made clear that in order to escape taxation on its shares it is not enough for a national bank to show merely that it is authorized to engage in some line of business carried on by less heavily taxed non-banking concerns; strict proof is further necessary that the moneys of the bank were in fact engaged in substantial amount in such a business. Failing to escape under section 5219, the Louisiana banks then invoked the Fourteenth Amendinent. Their argument was that the state was violating the equal protection clause in taxing banks more heavily than loan companies, finance and securities companies, pawnbrokers, homestead and building associations, federal joint stock land banks, life insurance companies, real estate unortgage and investment, or bond and investment brokers. As in the preceding case, this argument was emphatically rejected. There is a fundannental difference between banks, which make loans mainly from unoney of depositors, and the other financial institutions, which make loans mainly from the money supplied otherwise than by deposits.

Another attempt by a national bank to escape state taxation on its shares failed in Hoenig v. Huntington National Bank. ${ }^{19}$ The bank sought relief under section 5219 because building and loan associations, and mortgage and finance companies were more lightly taxed. The circuit court of appeals denied relief because of insufficient proof that these concerns were in substantial competition with national banks.

\section{Federal aNd State Instrunentalities}

The reason why national banks are subjected to state taxation only so far as Congress permits is of course that such banks are deemed to be an instrumentality of the federal government. And as the result of an implied limitation of the Constitution federal instrumentalities or agencies possess an immunity from state taxation. Conversely, the instrumentalities of the states enjoy a constitutional immunity frons federal taxation. The extent of these inmumities has been charted by the Supreme Court in an extensive line of decisions dating back to McCulloch $v$. Maryland ${ }^{20}$ in 1819. During one period there was a

18 (1933) 289 U. S. 60.

19 (C. C. A. 6th, 1932) 59 F. (2d) 479 , cert. den., (1932) 287 U. S. 648.

20 (1819) 4 Wheat. (17 U. S.) 316. 
tendency to enforce these reciprocal exemptions according to rigid and mechanical standards, with little regard to the actual effect that might be produced upon the government whose instrumentality was sought to be taxed. This tendency reached its peak in Long $v$. Rockwood, ${ }^{21}$ in 1928, when the Supreme Court held that a state could not constitutionally tax income received by a citizen as royalties for the use of patents issued to him by the United States. Within the last five years, however, the tide has been turning the other way. The emphasis now is being placed upon the conception that the principle of immunity "has its inherent limitations." 22 Technical interference by one government with the other is not enough, but the tax will be judged in the light of its practical effects. Immunity will not exist where no direct burden is laid upon the governmental instrumentality and there is only a remote, if any, influence upon the exercise of the functions of government. Thus the Supreme Court at its 1931 term expressly overruled the patent case, Long v. Rockwood, just four years after it had been decided.23

In line with this late tendency it is significant that of four cases before the Court during the 1932 term, in which the imposition of a tax was attacked on this general ground, the decision in each instance denied the immunity sought. Two of these cases were clear enough. Broad River Power Co. v. Query ${ }^{24}$ (already mentioned in another connection) involved a state excise on the production and sale of electric power. A power company claimed immunity upon the ground that it was generating current at a water power plant, which was constructed and was being operated pursuant to a license granted by the Federal Power Commission under the Federal Water Power Act and hence that the tax was upon a federal agency. The argument is unsubstantial. The tax is not upon the exertion of, and cannot be said to burden, any governmental function.

In Board of Trustees of the University of Illinois v. United States, ${ }^{20}$ federal customs duties had been exacted upon scientific apparatus imported by a state university for use in one of its educational departments. The university insisted that as an instrumentality of the state, and discharging a governmental function, it was entitled to import the articles duty free. But the Court pointed out that the levy of tariff

21 (1928) 277 U. S. 142.

22 Hughes, C. J., in Fox Film Corp. v. Doyal (1932) 286 U. S. 123, 128. See also the opinion of Mr. Chief Justice Hughes in Willcuts v. Bunn (1931) 282 U. S. 216; also Educational Films Corp. v. Ward (1931) 282 U. S. 379, limiting the effect of Macallen Co. v. Massachusetts (1929) 279 U. S. 620.

23 Fox Film Corp. v. Doyal, supra note 22.

24 Supra note 13.

25 (1933) 289 U. S. 48, (1933) 33 CoL. L. REV. 913. 
duties by Congress is attributable not only to the taxing power but also to the power of the federal government to regulate foreign commerce. Whether certain specific duties should be allocated to the one power or the other is a matter of policy which it is not the function of the judicial department to determine. And so far as the regulation of foreign commerce is concerned, the federal power is complete and is exercised to the exclusion of state authority. Thus there is no violation of the principle of immunity, for there can be no encroachment on the power of the state when none exists with respect to the subject over which the federal power has been exerted.

The two remaining decisions were both concerned with mineral leases. In Burnet v. A.T. Jergins Trust, ${ }^{26}$ the city of Long Beach, California, had acquired certain lands in connection with its municipal water system. Subsequently oil was discovered in the vicinity, and the taxpayer in question obtained from the city an oil and gas lease of the lands. The agreement stipulated that the lessee should receive $60 \%$ of the proceeds of oil and gas recovered and the city $40 \%$. The issue was whether the income derived by the lessee from the lease was subject to federal income tax. The Supreme Court held that it was, because the doctrine of implied immumity should be given a practical application and in the present instance the subject of the tax was so remote from any governmental function as to render the effect of the exaction inconsiderable so far as the activities of the city were concerned.

In reaching this result it was necessary to evade the authority of two earlier decisions with respect to income taxes-Gillespie v. Oklahoma ${ }^{27}$ and Burnet v. Coronado Oil \& Gas Co..$^{28}$ In the Gillespie case it had been held that net mcome derived by a lessee from sales of his share of oil and gas received under leases of Indian lands, which in effect constituted him an instrumentality of the United States in fulfilling its duties to the Indians, could not be subjected to state income taxation. In the Coronado case the State of Oklahoma had leased school lands to a private company for the extraction of oil and gas, and it was held that profit derived from the lease by the lessee was immune from federal income tax. In the argument of the Jergins case counsel for the government sought to distinguish this latter decision on the ground that the leased land there involved had been dedicated to the furtherance of a governmental function, whereas the Long Beach land, being a part of the mumicipal water system, was devoted to a function

26 (1933) 288 U. S. 508.

27 (1922) 257 U. S. 501.

28 (1932) 285 U. S. 393. 
which was not governmental. ${ }^{29}$ The Supreme Court, however, made no specific mention of this point of difference, but distinguished both the Coronado and Gillespie cases on the ground that in both. the burden upon the public use was more definite and direct than in the present case. It also said that in each of the earlier cases the sovereign had been acting as the trustee of an express trust with regard to the lands leased. Without making a detailed examination of the facts of those two cases, it may be said that the talk of "express trust" sounds a bit artificial. If the earlier decisions rested upon substantial grounds, there is no reason why the same policy should not control in the Long Beach case (unless for the reason that the operation of municipal waterworks is not a strictly governmental function). A court anxious to limit but unwilling to overrule a past decision, can always find grounds for distinguishing it; and when such a decision is restricted by later cases to its precise facts, it is safe to say that as an embodiment of legal principle its vitality is feeble.

The same diffrculty of distinguishing earher decisions was presented in the other mineral lease case decided by the Supreme Court during its last term-Indian Territory Illuminating Oil Co. v. Board of Equalization. $^{30}$ This concerned an oil and gas lease of Indian lands. Crude oil, extracted from the land and owned by the lessee, was held in storage tanks. The question was whether this oil could validly be subjected to state ad valorem taxation. In holding the tax constitutional, the Court had to distinguish Jaybird Mining Co. v. Weir. ${ }^{31}$ There an ad valorem tax upon ores mined under a lease of Indian land was held to be invalid. The only distinction in fact between the two cases was that in the Jaybird case the ore was still on the leased land and the lessee's portion had not yet been segregated from the share belonging to the Indians; whereas in the Indian Territory Co. case the Indians had received their share in full and the lessee's oil had been removed, commingled with other oil and was stored in the lessee's own tanks. These factual differences were held to justify a different result, but again one may suspect that if the Court had felt that the Jaybird decision had much life, it would have regarded such differences as unsubstantial.

Speakimg of fine distinctions it is of interest also to compare Indian

29 Citing South Carolina v. United States (1905) 199 U. S. 437. In this case it was held that federal license taxes might be imposed upon liquor dispensaries operated by the state of South Carolina. The Court took the view that the exemption of state agencies and instrumentalities from national taxation should be limited to those which are of a strictly governmental character.

30 (1933) 288 U. S. 325.

31 (1926) 271 U. S. 609. 
Territory Illuminating Oil Co. v. Board of Equalization with the earlier case of Gillespie v. Oklahoma. Both involved oil and gas leases of Indian lands. In the latter it was held that a state may not levy an income tax upon the net income derived by the lessee from the sale of his share of the minerals extracted. In the former it was held that a state may constitutionally levy a property tax upon oil extracted from the leased land and held by the lessee. If immunity is to be determined in accordance with reabities and with a view to the actual effect of the tax sought to be imposed, this comes close to being a theoretical distinction without a practical difference. The truth is that Gillespie v. Oklahoma, Burnet v. Coronado Oil \& Gas Co., and Jaybird Mining Co. v. Weir in spite of their recent dates $(1922,1932$ and 1926 respectively), are all out of line with the decisions which now inust be regarded as dommant. If immunity is to be tested by the practical considerations which the Court has been stressing the last few years, these cases should be frankly discredited. In this connection it is of interest to note that in the Coronado case in 1932 a dissenting minority of four judges urged that the Gillespie case should be definitely overruled. ${ }^{32}$

Before leaving the subject of immunity mention should also be made of the decision of the Supreme Court of California in People v. Standard Oil Co. ${ }^{33}$ holding that the state could collect from a distributor of gasoline a tax based upon sales to the army post exchange located on the Presidio military reservation at San Francisco. ${ }^{34}$ The California court thought that the case was distinguishable from Panhandle Oil Co. v. Mississippi, ${ }^{35}$ wherein the United States Supreme Court held that a state could not constitutionally impose a similar tax upon sales of gasoline to the United States for the use of the Coast

32 The situation in the Coronado case was further complicated by Group No. 1 Oil Corp. v. Bass (1931) 283 U. S. 279. There it was held that federal income tax could be imposed upon the profits derived by a lessee of school lands in Texas under an oil and gas lease. The basis of distinction between this and the Coronado case was that according to the Texas law the so-called "Iease" was actually a present sale of the minerals, whereas under the Oklahoma law in the Coronado case a true lease was involved. The majority of the Court thought that this feature of the Texas law was sufficient to distinguish the Bass case from the Gillespie case, but that the Coronado case could not be distinguished from the Gillespie case. The minority thought that the difference in the legal nature of the "leases" was unimportant and that the Bass case bad in effect discredited the Gillespie decision.

83 (1933) 85 Cal. Dec. 559, 22 P. (2d) 2.

34 Similar sales have been held non-taxable in Maryland on the ground that the statute should be construed to exclude them. United States v. Cordy $(D$. Md. 1932) $58 \mathrm{~F}$. (2d) 1013.

35 (1928) 277 U. S. 218. 
Guard and a veterans' hospital. It was felt that the army post exchange was a coöperative organization largely engaged in business of a private nature and should not be regarded as one of those agencies through which the federal government directly exercises its constitutional or sovereign power.

\section{Interstate COMMerce}

Gasoline taxes were also the subject of two cases in the United States Supreme Court involving the question of state interference with interstate commerce. The first was Nashville, Chattanooga \& St. Louis $R y$. v. Wallace. ${ }^{36}$ The situation was this: An interstate railroad purchased gasoline in large quantities outside the state of Tennessee and brought the same into that state, where it was placed in the company's own storage tanks. The gasoline was withdrawn from storage and used by the railroad as required as a source of motive power for moving its interstate trains in Tennessee and other states. A tax of two cents per gallon on this gasoline was levied by the state under a statute imposing a privilege tax on persons carrying on the business of selling or storing or distributing gasoline within the state. On behalf of the railroad it was contended that this tax was an unconstitutional burden on interstate commerce, for two reasons: first, because the tax was imposed on the gasoline while still a subject of interstate commerce in the course of transportation from points of origin outside the state to other outside points; secondly, because the tax was in effect one upon the use of the gasoline in the company's business as an interstate carrier. The Court sustained the tax as against both lines of attack. As to the first point, it stated that the gasoline, upon being unloaded and stored, ceased to be a subject of transportation in interstate coinmerce and lost its immunity as such from state taxation. As to the second point, the tax was not one imposed upon the use of the fuel as an instrument of commerce, but on the contrary was imposed with respect to the storage and withdrawal from storage of the gasoline, which activities were completely accomplished before the interstate use began. Therefore the burden of the tax was too indirect and remote from the function of interstate commerce itself to transgress constitutional limitations.

This decision recalls the one handed down a year earlier in Eastern Air Transport, Inc. v. South Carolina Tax Comm., ${ }^{37}$ in which the Supreme Court upheld a state tax on the sale of gasoline as applied to gasoline purchased within the state for use in airplanes engaged in interstate transportation. Both decisions are to be contrasted with 
Helson v. Kentucky, ${ }^{38}$ decided in 1929. There the same Court held unconstitutional a state statute imposing a tax upon the use of gasoline, in so far as it affected gasoline purchased outside the state for use within the state as fuel upon a ferry boat engaged in interstate commerce. Thus a distimction lies between an excise based upon the sale or storage or withdrawal from storage on the one hand and an excise based upon the actual use of the gasoline in an interstate vehicle on the other.

This line of distinction between valid and invalid gasoline taxes is drawn even more finely in the second of this year's decisions-Edelman v. Boeing Air Transport, Inc., ${ }^{30}$ involving an excise levied by the state of Wyoming. The taxpayer was maintaining an airplane service for interstate transportation. The gasoline in question was purchased outside of Wyoming, then brought into that state and used there in the taxpayer's planes in interstate commerce. The statute imposed a license tax on wholesalers amounting to four cents per gallon on all gasoline sold or used within the state. It contained also the further provision that every person who should use any gasoline within the state upon which such tax had not been paid by any wholesaler, slould limself pay a like tax. Under this latter clause the state souglit to collect a tax with respect to the gasoline above mentioned, and the Supreme Court leeld that the state could constitutionally do so. At once we are confronted with the question of how this decision can be reconciled with Helson v. Kentucky. In both cases the respective statutes purported to levy a tax based on the "use" of gasoline within the state; in both also the gasoline in question was consumed as fuel in an interstate vehicle. But the Wyoming statute was rescued from the fate of the Kentucky statute by an ingenious interpretation of the word "use." In the Kentucky case, "use" meant the consumption of the fuel in the engines of the ferry boat. But as construed by the state authorities, what the Wyoming statute meant by "use" was not the consumption of gasolime in propelling the airplanes but the withdrawal of it froin the storage tanks at the airport preliminary to putting it into the planes. Thus it became possible to identify the case with Nashoille, Chattanooga \& St. Louis Ry. v. Wallace, instead of with Helson v. Kentucky. To make this nice distinction clear perhaps it is worth while quoting from Edelman v. Boeing Air Transport, Inc.:

"As the statute has been administratively construed and applied, the tax is not levied upon the consumption of gasoline in furnishing motive power for respondent's interstate planes. The tax is applied to the stored gasoline as it is withdrawn from the storage tanks at the airport and

38 (1929) 279 U. S. 245.

39 (1933) 289 U. S. 249. 
placed in the planes. No tax is collected for gasoline consumed in respondent's planes either on coming into the State or on: going out. It is at the time of withdrawal alone that 'use' is measured for the purposes of the tax. The stored gasoline is deemed to be 'used' within the State and therefore subject to the tax, when it is withdrawn from the tanks. . . .

"A State may validly' tax the 'use' to which gasoline is put in withdrawing it from storage within the State, and placing it in the tanks of the planes, notwithstanding that its ultimate function is to generate notive power for carrying on interstate commerce. Such a tax cannot be distinguished from that considered and upleld in Nashville, Chattanooga \& St. Lousis Ry. v. Wallace, supra." 40

So far as Helson v. Kentucky is concerned, the tax there could not have been saved in this way even if the state could have anticipated the need for such an interpretation of its statute. For (as the Court points out in its opinion in the Edelman case) the facts there were that the Kentucky statute taxing the use of gasoline had been applied to that. purchased and placed in the tanks of the ferry boat outside the state. Hence the only possible act occurring inside the state which could afford a basis for the tax was the actual consumption in the engines.

Reviewing the whole line of cases it seems evident that except in this special case where the fuel is placed in the tanks of the vehicle outside the state, a state need have no difficulty in levying an excise based upon the gasoline consumed in these interstate vehicles. All that is necessary is for the state to take care to draft or interpret its legislation in the right way. Thus by the familiar process of limiting the force of the decision to its exact facts, the Supreme Court has reduced Helson v. Kentucky to a position of practical insignificance.

\section{Franchise Taxation}

A case dealing with corporation franchise taxation, which has attracted some attention, is Anglo-Chilean Nitrate Sales Corp. v. Alabama.41 The taxpayer was a New York corporation, which had qualified to do business in Alabama. A franchise tax was assessed against it under an Alabama statute which provided that foreign corporations "doing business in this State" should pay an annual franchise tax of two dollars on each one thousand dollars "of the actual amount of capital employed in this State." 42 From the date of its qualification in Alabama to the time of the assessment, the Anglo-Chilean Corporation had been engaged in the business of importing nitrate. The nitrate, in 100-pound bags, was brought into the port of Mobile and there stored in a public warehouse and kept in the original packages, until

40 Ibid. at $251-252$.

11 (1933) 288 U. S. 218.

12 Ala. Stats. 1927, No. $163, \S 54$. 
sold and delivered to the ultimate consumers. All sales were made through a salesman, upon orders which were subject to approval by the company at its New York office. No other business was transacted in Alabama, and the company had no other property and employed no other capital there. The tax assessed was based upon the value of the mitrate then stored within the state. The company maintained that such assessment was repugnant both to the commerce clause and to that clause of article I, section 10, of the federal Constitution which provides that "No State shall, without the Consent of the Congress, lay any Imposts or Duties on Imports or Exports, except what may be absolutely necessary for executing its inspection Laws." By a six-tothree vote the federal Supreme Court held the tax unconstitutional.

In the majority opinion the Court began its consideration of the case by an inquiry into the precise nature of the tax. This involved the interpretation of the state law-a question on which the state tribunals are the ultimate authority. It is, of course, common for states to levy so-called franchise taxes, which are in substance excises upon the right or privilege of doing business in corporate form. But from an examination of the state decisions the Supreme Court concluded that this was not the nature of the Alabama tax. What it did determine was that the tax was laid upon the actucal doing of business, rather than upon the privilege of doing business, within the State. This may seem a fine distinction, but its consequences are far-reaching. It then becomes immaterial that the foreign corporation may have asked for and received the privilege of doing a local business, since in fact that privilege had not been exercised. The tax must be regarded as an excise upon the only business actually done-which was the business of importing nitrate. Once this mitial premise of the Court, as to the meaning of the state law, be accepted, the rest of the case becomes comparatively simple and the conclusion reached is amply supported by previous authority.

It is plain that a state may not tax imported goods so long as they remain in the original packages and have not yet lost their distinctive character as imports. And ever since the decision in Broven v. Mary$\operatorname{land}^{43}$ in 1827 , it has been settled that a state license fee or occupation tax imposed on an importer selling imported goods in the original packages is likewise repugnant to the imports clause of the Constitution. Now if the Alabama tax was based upon the business actually done by the Anglo-Chilean Corporation, it was an excise upon the business of importing and this seems indistinguishable from any other license fee

43 (1827) 12 Wheat. (25 U. S.) 419. 
or occupation tax on importers. Certainly the exaction is no less objectionable because it is confined to corporations. To quote the Court:

"Alabama was powerless, without the consent of Congress, to tax the nitrate before such sales or to require appellant by the payment of occupation or franchise tax or otherwise to purchase from it the privilege of selling goods so imported and handled. Brown v. Maryland, 12 Wheat. 419, 436, 442-44." 14

This latter part of the Court's argument was not questioned by the dissenting judges. What they did was to attack the initial premise of the majority as to the meaning or effect of the state law. Looking, as did the majority, to the Alabama statutes as construed by the state tribunals, they drew the opposite deduction. As they understood the Alabama law, the tax was levied not upon the actual transaction of business, but upon the privilege of doing business. Starting from this opposite premise, the development of the case becomes altogether different. Several new problems then arise. We have a foreign corporation which has sought for and obtamed the privilege of doing a local business. But in fact it has done no such business. Thus the question is presented-may a state constitutionally tax a foreigu corporation upon the possession of the privilege of doing a local business when that privilege has been granted but never exercised?

Had it been a domestic corporation instead of a foreign corporation that was involved, the answer to this question could have been found in another decision handed down by the Supreme Court, during the last term. This was Detroit International Bridge Co. v. Corporation Tax Appeal Board of Michigan.45 The taxpayer here was a Michigan corporation engaged in operating the international bridge spanning the river between Detroit and Sandwich, Ontario. Doing no other business, it was engaged exclusively in foreign commerce. Nevertheless the state of Michigan exacted from the corporation a franchise tax. Unlike the Nitrate case, there was here no room for doubt as to the nature of the tax sought to be imposed. Under the Michigan law it was perfectly clear that the tax was laid upon the privilege of transacting and not upon the actual transaction of business. In fact the statute specifically stated that the intent was to impose the tax "upon every corporation, foreign or domestic, having the privilege of exercising corporate franchises within this state, irrespective of whether any such corporation chooses to actually exercise such privilege during any taxable period." 40 The only question was whether it was constitutional to collect such a tax from -a domestic corporation engaged exclusively in foreign com-

14 Supra note 41 , at 226.

45 (1932) 287 U. S. 295.

16 Mich. Stats. 1921, No. 85, §4, as amended 1929, No. 175. 
merce. The Supreme Court felt that the critical issue in the case was whether the corporation had power to carry on any business that was not within the protection of the commerce clause. Since it appeared that the company did have the power to carry on certain local busmess within the state, it was held that the tax could constitutionally be imposed. The corporation possessed the privilege of doing a local business and this privilege could be taxed regardless of what foreign business the corporation might choose to do or whether it chose to do any business at all.

Getting back now to the Nitrate case, the question presented by the minority opinion was whether the same result should follow where a foreign corporation is granted but does not exercise the privilege of doing a local business, confining itself instead to the business of importing which is in itself beyond the reach of the state's taxing power. The minority judges thought it should make no difference whether the corporation was domestic or foreign and said that the state was competent to tax such a privilege or grant of benefits which went beyond any conferred by the federal Constitution. It is hard to see why this should not be so, although some doubt is cast upon the point by Ozark Pipe Line Corp. v. Monier. ${ }^{\text {.7 }}$

Assuming that the Anglo-Chilean Corporation might be taxed upon its unexercised privilege to transact a local business, a further difficulty arises as to the measure of the tax. The statute provided that the franchise tax should be ineasured by the "actual anount of capital employed in this State;" and since the only capital which the company had in Alabauna was the imported nitrate, the assessment made by the state authorities was based upon the value of that. But as imports, this property was immune from direct taxation. The problem then is whether the excise upon a privilege admittedly subject to taxation may be measured by such immune property. It certainly seems that the immunity of the thing taken as the measure is not necessarily fatal to the validity of an excise tax. Educational Films Corp. v. Ward ${ }^{48}$ and Pacific Co. v. Johnson $n^{49}$ illustrate that. The really critical question would seem to be whether the measure taken bore any reasonable relation to the privilege conferred, or whether it was a merely arbitrary standard. In other words, is there a reasonable relation between the privilege of doing a local business and the value of inported property which at no time is used in connection with any local business? This is

47 (1925) 266 U. S. 555. But compare the comment on this decision in the majority and minority opinions in the Nitrate case, supra note 41 , at 224-225 and 236-237. Cf. also Ficklen v. Taxing Dist. of Shelby County (1892) 145 U. S. 1.

48 Supra note 22 ; see especially pp. 389-391.

49 (1932) 285 U. S. 480. 
an interesting problem, and to the present writer, for one, the solution does not seem simple. The dissenting judges, however, appeared to feel no diffculty in finding the necessary relation, although Mr. Justice Cardozo's exposition of the point is not as lucid as might be desired. But whatever the right answer to this question may be, the Nitrate case cannot be regarded as setting any precedent upon it, for the majority of the Court do not reach the point nor even mention it.

In fact, in spite of the interest which the case has attracted, it does not decide much of anything. The only point really put at issue between the majority and minority opinions is that of the interpretation of the state law. Having reached opposite conclusions on that score, the two opinions follow paths which do not cross. The remainder of the majority argument involves merely a conventional application of old law. As to what is the correct view of the Alabama statute, there is room for debate. But at all events the question is of little general interest, involving merely the construction of a local statute-a matter of state law which should be placed beyond cavil by the state tribunals. In view of these circumstances one may venture the prediction that in the future development of the law, Anglo-Chilean Nitrate Sales Corp. v. Alabama is not destimed to be an authority of much importance.

\section{INHERITANCE TAXation}

In the field of inheritance taxation, the year has produced no striking developments. Probably the most important case is Burnet $v$. Brooks, ${ }^{50}$ already discussed under the head of jurisdiction.

In general the most fertile source of litigation within this field is to be found in the statutory provisions taxing transfers inter vivos. In order to prevent evasion the various inheritance tax laws regularly provide for the taxation of transfers of property (1) made in contemplation of death or (2) intended to take effect in possession or enjoyment at or after death. Both of these clauses are troublesome, but the second especially has given rise to innumerable disputes both as to interpretation and as to constitutionality. The issue whether a transfer is intended to take effect at or after death, or prior to death, commonly hinges upon two factors-first, the reservation by the transferor of the income of or other beneficial interest in the property transferred, and secondly, retention by him of the power of revocation. If both these rights have been reserved, it is undisputed that the transfer has not taken effect in possession or enjoyment until the death occurs and hence that a tax is payable. When one only is reserved, the zone of controversy is reached. Often a property-owner makes an irrevocable

50 Supra note 1. 
transfer of title, keeping for himself the income or enjoyment of the property during his life. Under these circumstances the courts with few exceptions $^{51}$ have held that the transfer is taxable. This result was reached in a recent Wisconsin case involving a conveyance of real estate by deed, where the donor's right to the life income from the property had been based merely upon an oral understanding. ${ }^{52}$

The converse situation is presented when an owner conveys the title to property in trust and disposes of all the beneficial interest, saving for himself only a power of revocation. Here, most of the decisions under the various state statutes are to the effect that the possession and enjoyment vest in the beneficiaries as soon as the transfer is made, rather than at the death of the transferor, and hence that no tax is due.53 This view has been recently accepted in Maryland when the question came to the supreme court of that state for the first time. ${ }^{54}$ In discussing the statutory provision taxing transfers intended to take effect in possession after death, the court explained the legislative purpose in the following language:

"The obvious purpose and intent of the statute was to strike at evasions of the collateral inheritance tax statute by imposing the tax upon all gifts or grants inter vivos by instruments of a quasi testamentary character, intended to take effect in possession at the death of the settlor but leaving to the settlor the beneficial enjoyment and/or control of the same during his life. It was not intended to impose the tax upon estates transferred inter vivos by deed or other instrunent by which the grantor completely parted with all interest in or control over the estate, for the language employed is inconsistent with any such intention." 55

This would appear to be a fair statement of the legislative intent, but if so can it fairly be said that the grantor has completely parted with all control over the estate, when he has reserved full power to revoke the transfer? When the grantor retains till his death the ability to retake the property for himself or to make any new disposition of it that may suit his fancy, the case would seem to be within the spirit of

51 The most striking exception to the usual rule of construction is to be found in the decisions of the United States Supreme Court in May v. Heiner (1930) 281 U. S. 238; Burnet v. Northern Trust Co. (1931) 283 U. S. 782; Morsman v. Burnet (1931) 283 U. S. 783; McCornnick v. Burnet (1931) 283 U. S. 784. The day following the decision in the three cases last cited, the federal revenue act was amended specifically to include transfers under which the transferor has retained for his life "the possession or enjoyment of, or the right to the income from, the property." 46 STAT. (1931) 1516, 26 U. S. C. A. (Supp. 1933) \$1094.

02 In re Ogden's Estate (1932) 209 Wis. 517, 244 N. W. 571. For an illustration of the application of the usual rule that transfers of this sort are taxable, where the true nature of the transaction was somewhat camouflaged, see In re Perry (1932) 111 N. J. Eq. 176, 162 Atl. 146. See (1933) 46 Harv. L. REv. 525. 53 Notes (1927) 49 A. L. R. 864; (1930) 67 ibid. 1247.

64 Downes v. Safe Deposit \& Trust Co. (1932) 163 Md. 30, 161 Atl. 400.

E5 Ibid. at 33, 161 Atl. at 401. 
the statute; and to hold the transfer taxable would hardly be an undue strain upon the letter.

So far as the federal estate tax is concerned, this question of construction does not arise because Congress has specifically provided that a tax shall be collected upon inter vivos transfers which the decedent, at the time of his death, possessed the power to revoke. ${ }^{50}$ A more novel problem under the federal legislation was presented to the Supreme Court in Burnet v. Guggenheim. ${ }^{57}$ The respondent in 1917 had conveyed property to trustees for the benefit of his children, reserving to himself the right to revoke the trusts. Had he then died without taking further action, the property would of course have been subject to estate tax under the specific statutory provision just referred to. But he did take action before his death and in 1925 cancelled and surrendered his power of revocation. The rights of the beneficiaries in the trust property thus became absolute before the death of the grantor. Even so, an estate tax might have been assessed, provided the cancellation of the power to revoke had been made "in contemplation of death," as that phrase is understood in the tax laws. For the federal revenue acts specify that where a decedent has relinquished such a power in contemplation of his death, the trust property shall be included in his estate for purposes of the estate tax ${ }^{58}$ But since the government made no claim that the power had been surrendered in contemplation of death, no basis remained for the imposition of an estate tax. However, the Commissioner of Internal Revenue resorted to the general tax upon gifts which had been newly provided for in the Revenue Act of 1924, and made an assessment against the donor accordingly.

The Supreme Court did not doubt that the result of the entire transaction was the making of a gift within the meaning of the statute. But two steps were involved and the difficulty was-did the taxable transfer take place in the year when the revocable deeds were delivered and the trusts created, or in the year in which the power of revocation was rehinquished? This was a question of legislative intention and the legality of the tax in Burnet v. Guggenheim hinged upon the answer, because the original transfers were made prior to the enactment of the gift tax whereas the power had been surrendered while these provisions were in effect. The Court concluded that it must have been the

56 Revenue Act of 1926, \$302, 44 Stat. (1926) 70, 26 U. S. C. (1926) \$1094. 57 (1933) 288 U. S. 280. $\$ 1094$.

68 See Revenue Act of 1926, §302, 44 Stat. (1926) 70, 26 U. S. C. (1926)

59 Revenue Act of 1924, §§ 319 et seq., 43 Stat. (1924) 313. These provisions were repealed by the Revenue Act of 1926, \$1200, 44 STAT. (1926) 125, 26 U. S. C. (1926) \$1260a. 
intent of Congress to lay the tax upon the final surrender. The act was aimed at transfers of title that have the quality of a gift, and a gift is not consummate until put beyond recall. The gifts in question acquired substance and reality for, the first time when the deeds became absolute through the cancellation of the power of revocation. It may be noted that when Congress revived the gift tax in the Revenue Act of 1932, the rule approved in this decision was specifically incorporated into the statute. ${ }^{60}$

To get back to the federal estate tax, it will be remembered that revocable transfers are taxable when the transferor dies leaving the power unexercised. Actually the statute is even more comprehensive. Section 302(d) of the Revenue Act of 1926 provides that for purposes of the estate tax there shall be included in the value of the gross estate property of which the decedent has at any time made a transfer, by trust or otherwise, "where the enjoyment thereof was subject at the date of his death to any change through the exercise of a power, either by the decedent alone or in conjunction with any person, to alter, amend, or revoke..." 61 The question has been litigated a number of times whether under this clause a transfer in trust is taxable where the transferor has reserved the right to alter or inodify the trust, with the express limitation that no change may be made in favor of himself or his estate. In the lower federal courts, decisions upon the point have been conflicting. ${ }^{62}$ In order to end this conflict the Supreme Court granted a writ of certiorari in Porter v. Commissioner of Internal Revenue. ${ }^{63}$ As a matter of construction it held that the transfer in question was taxable, thus giving to the language of Congress what would seem to be its natural meaning.

With the statute so construed, the further constitutional question was raised whether its application was consistent with due process of law, in view of the fact that the original transfer had been made prior

60 "The tax shall not apply to a transfer of property in trust where the power to revest in the donor title to such property is vested in the donor, either alone or in conjunction with any person not having a substantial adverse interest in the disposition of such property or the income therefrom, but the relinquishment or termination of such power (other than by the donor's death) shall be considered to be a transfer by the donor by gift of the property subject to such power, and any payment of the income therefrom to a beneficiary other than the donor shall be considered to be a transfer by the donor of such income by gift." Revenue Act of 1932, §501, 47 STAT. (1932) 245, 26 U. S. C. A. (Supp. 1932) \$1136a.

6144 StaT. (1926) 71, 26 U. S. C. (1926) \$1094(d).

62 Such a transfer was held not to be taxable in Brady v. Ham (C. C. A. 1st, 1930) 45 F. (2d) 454, and Cover v. Burnet (App. D. C. 1931) 53 F. (2d) 915. Contra: Porter v. Commissioner of Internal Revenue (C. C. A. 2d, 1932) 60 F. (2d) 673.

63 (1933) 288 U. S. 436. 
to the enactment of the statutory provision in question, although the death had not occurred until after such enactment. On this point the taxpayer relied on the well-known and much-discussed decision in Nichols v. Coolidge. ${ }^{64}$ This and its companion case, Coolidge v. Long, ${ }^{\text {as }}$ (decided four years later), were both concerned with the same transfer of property in trust. The two cases were alike except that the first involved the federal estate tax and the second the Massachusetts succession tax. The original transfer had been made when there were no such taxes in force, but the transferor died after both federal and state legislation had been enacted. The facts were rather unusual in that the trust was irrevocable, the settlor had retained no beneficial interest and the only bearing the latter's death had on the situation was that the rights of certain beneficiaries were subject to divestment in the event that they should predecease the settlor. The latter's death had removed this chance of divestment. Under these circumstances, since no interests were left in the settlor to pass from him upon his death, the transfer might well have been held non-taxable merely as a matter of statutory construction, upon the ground that it had taken effect when made and not at death. In fact, so far as the federal tax is concerned, this result would seem to be required by other decisions of the Supreme Court. ${ }^{66}$ But the Massachusetts court held otherwise, and in Nichols v. Coolidge the federal Supreme Court accepted without discussion the conclusion of the trial court that the transfer was within the terms of the statute. The two statutes, being construed in this way, were both held unconstitutional as applied to the facts in question. In Nichols v. Coolidge, the Court made the following statement, which was again repeated in Coolidge v. Long:

"And we must conclude that $\$ 402$ (c) of the statute here under consideration, in so far as it requires that there shall be included in the gross estate the value of property transferred by a decedent prior to its passage merely because the conveyance was intended to take effect in possession or enjoyment at or after his death, is arbitrary, capricious and amounts to confiscation. Whether or how far the challenged provision is valid in respect of transfers made subsequent to the enactment, we need not now consider." ${ }^{67}$

Thus the Supreme Court invoked the doctrine which it has established within the last decade, that retroactive excise taxation is a denial of due process of law. ${ }^{6 S}$ The language quoted would seem to indicate

64 (1927) 274 U. S. 531.

65 (1931) 282 U. S. 582.

66 See Shukert v. Allen (1927) 273 U. S. 545; Reinecke v. Northern Trust Co. (1929) 278 U. S. 339. 596.

67 Supra note 64 , at 542-543, quoted in Coolidge v. Long, supra note 65 , at

68 See Untermyer v. Anderson (1928) 276 U. S. 440; Blodgett v. Holden (1927) 275 U. S. 142. 
that this doctrine has general application to transfers taking effect at death where the transfer was inade prior to the enactment of tax laws and the transferor's death occurs after such enactment. The Court had hardly made this broad statement, however, before it began to limit it. Within a year it had held that the doctrime laid down in Nichols $v$. Coolidge had no application to a transfer taking effect at death, where the transferor had reserved a right of revocation. This was in Saltonstall v. Saltonstall, ${ }^{69}$ involving the Massachusetts inheritance tax. In Reinecke v. Northern Trust Co. ${ }^{70}$ the same decision was made with respect to the federal estate tax. The case now under considerationPorter v. Commissioner of Internal Revenue-holds that this result is unaffected by the fact that the settlor possessed no power to retake the trust property for himself. He did preserve the right to make any other disposition thereof, and hence his death, by terminating such right, was "the source of valuable assurance passing from the dead to the living." 71 This was the event upon which Congress based the tax, and since it occurred subsequent to the passage of the tax legislation, no objection can be made on the score of retroactivity.

This hmitation upon the scope of Nichols v. Coolidge was further developed in Gwinn v. Commissioner of Internal Revenue, ${ }^{72}$ relating to a joint tenancy. The federal revenue acts, like inost of the state inheritance tax laws, specifically provide for the levy of a tax upon the transfer of property contributed to a joint tenancy or tenancy by the entirety by one tenant and acquired in full by the other by right of survivorship upon the death of the first. ${ }^{73}$ In the Gwinn case the question was whether such a tax could constitutionally be imposed where the joint tenancy was created prior to the enactment of the estate tax, the death of the first joint tenant occurring afterwards. Again, the Court held that Nichols $v$. Coolidge did not apply. When the joint tenancy was created, the rights of the possible survivor were not then irrevocably fixed, since under the state laws the joint estate might have been terminated through voluntary action by either party. This power was not extinguished until the death of one tenant, which therefore became the generating source of definite accessions to the survivor's property rights. In other words, the transfer was in substance the same as the revocable transfers in Saltonstall $v$. Saltonstall and Reinecke v. Northern Trust Co. The Coolidge cases were distinguished on the

69 (1928) 276 U. S. 260.

70 Supra note 66.

71 Supra note 63 , at 444.

72 (1932) 287 U. S. 224, (1933) 21 CALIF. L. Rev. 286. $\$ 1094$.

78 See Revenue Act of 1926, \$302, 44 SrAr. (1926) 70, 26 U. S. C. (1926) 
ground that in them "the rights of the survivors became finally and definitely fixed before the passage of the act-nothing was added as the result of death." 74

This brings us to a case which would appear to be of some significance-Third National Bank \& Trust Co. v. White. ${ }^{75}$ The facts here were the same as the Gwinn case, except that the tenancy instead of being joint was a tenancy by the entirety. The lower federal courts upheld the validity of the tax. Their holding was affirmed by the Supreme Court without opinion in a uneunorandum decision which merely cited Gwinn v. Commissioner of Internal Revenue and Tyler v. United States. ${ }^{76}$ Apparently the Court thought that there was insufficient distinction between the cases to justify further discussion. But it is to be remembered that in the Gwinn case the fact was stressed that the joint tenancy could be terminated by the voluntary action of either tenant, which fact made it possible to assimilate the case with that of the ordinary revocable transfer. With respect to the tenancy by the entirety on the other hand, there is normally no such power vested in one party to destroy the tenancy. ${ }^{77}$ It is therefore difficult to see how this case can be assimilated with that of a revocable transfer. And there is nothing in the opinion in the Greinn case to reveal how the Court would distingnish the tenancy by the entirety from the transfer in Nichols v. Coolidge. In other words, in the case where light was needed the Court furnished none, but contented itself with a mere per curiam decision.

The only logical conclusion to be drawn from this decision is that the authority of Nichols v. Coolidge must be still further limited. The earlier cases seemed to draw the lime between irrevocable transfers, and those which in some way or other could be revoked or altered by voluntary action. But if a tax may be imposed in the case of the indestructible tenancy by the entirety, this line of distinction no longer holds. Either the Coolidge cases are to be completely discredited or else their application must be confined within still smaller limits. A basis for such further limitation may be found in an additional distinction of fact between the Coolidge cases and the contrasting decisions in which the tax has been upheld as against the claim of retroactivity. In the Coolidge cases, not only was the transfer irrevocable but also the beneficiaries were presently possessed of the full enjoyment

74 Supra note 72, at 229.

T5 287 U. S. 577, aff'g, per curiam (C. C. A. 1st, 1932) 58 F. (2d) 1085, aff'g, per curiam (D. Mass. 1930) 45 F. (2d) 911.

76 (1930) 281 U. S. 497.

77 See (1933) 46 HaRv. L. Rev. 718. 
of the property. The effect of the settlor's death was negative rather than positive. It caused to vest in them no new interest and did not increase their present enjoyment which already extended to the full fruits of the property. All that the settlor's death did was to remove the chance that these rights might be terminated with respect to any beneficiary who should predecease the settlor-that what had been vested might be divested. This chance of divestment was not deemed sufficient to render the succession incomplete.

But in the cases in which the tax has been upheld, the situation was otherwise. The settlor's death caused the beneficiaries to enjoy more than they had enjoyed before. So with the tenancy by the entirety. The tenancy may be irrevocable and indestructible. It may be that technically no new property interest passes to the surviving tenant upon the death of the other. Yet practically the survivor has larger rights of enjoyment than he had before. Thus it has been possible for the Court to say that the death of one tenant becomes the "generating source" of important and definite accessions to the property rights of the other. ${ }^{78}$ Until the death, in other words, the succession is incomplete. This thing that is brought about at death is of itself sufficient to support a tax. Hence, since the death occurred after the statute was passed, it is immaterial that the original transfer was made before. But in the Coolidge cases, where the death did not enlarge the present rights or enjoyment of the beneficiaries, the Court felt that what happened at the death was not enough of itself to support a tax. ${ }^{79}$ In order to have a taxable subject, it was felt necessary to include the original transfer along with the change that occurred at death. And since that transfer was made before any tax statute was passed, the tax is deemed retroactive and hence unconstitutional. This would appear to be the ultimate basis of the Coolidge cases-at least, if Third $\mathrm{Na}$ tional Bank \& Trust Co. v. White is to be taken at its face value. Of course, there is an element of danger in accepting the logical consequences of a per curiam decision. One cannot be certain of its implications.

Assuming that the statute were passed before the original transfer was made, so that the retroactive feature is not present, there is no constitutional objection to a tax in any of these cases. The Court recognized this in Coolidge v. Long, when it said:

78 See Tyler v. United States, supra note 76, at 504.

70 "The fundamental question here is whether rights had so vested prior to the taking effect of the tax statute that there was thereafter no occasion in respect of which the excise might constitutionally be imposed." Coolidge v. Long, supra note 65 , at 596 . 
"Undoubtedly the State has power to lay such an excise upon property so passing after the taking effect of the taxing Act." 80

This dictum was quoted with approval in still another case decided by the Supreme Court at the last term-Guaranty Trust Co. of New York v. Blodgett. ${ }^{81}$ There the decedent had executed an irrevocable deed of trust in favor of certain beneficiaries, but reserved for herself the enjoyment of the income from the trust property during her life. Upon her death a tax was imposed under the Connecticut succession tax act. Although the statute had not been given any retroactive application, it was argued that no tax could constitutionally be imposed. The argument is obviously fallacious, as the Court held. These taxes need not be confined to revocable transfers. Nor is it necessary that any interest in the title pass at death. The shifting of economic benefits at that time is enough.

\section{The FederaI Income Tax}

A. Income from Trusts. Out of the flood of litigation over the federal income tax, space does not permit mention of more than a few cases. Two which probably are as noteworthy as any relate to the taxation of the income of trusts. The trust is a device which readily lends itself to schemes for the evasion of taxes. In the field of inheritance taxation, the inter vivos transfers which create the need for provisions taxing transfers intended to take effect in possession or enjoyment at or after death, are usually made in trust. Similarly, the man who seeks to evade income taxes naturally turns to the trust. By placing property in trust he may succeed in getting the income attributed to other taxpayers, while at the same time retaining some control for himself or seeing that the income is devoted to the purposes that he desires. In order to prevent evasion in this fashion Congress inserted in the Revenue Act of 1924 a provision to the effect that the income of revocable trusts shall be taxed to the settlor. Section $219(\mathrm{~g})$ of that $\mathrm{Act}^{82}$ reads as follows:

"Where the grantor of a trust has, at any time during the taxable year, either alone or in conjunction with any person not a beneficiary of the trust, the power to revest in himself title to any part of the corpus of the trust, then the income of such part of the trust for such taxable year shall be included in computing the net income of the grantor."

In Reinecke v. Smith, ${ }^{83}$ this clause was under attack. The taxpayer had in 1922 created certain trusts for the benefit of his wife and children. The trustees named were the grantor, a son who was one of the beneficiaries, and a bank. The trust agreements stipulated that the

80 Ibid. at 596.

81 (1933) 287 U. S. 509, (1933) 21 CarlF. L. Rev. 525.

8243 STAT. (1924) 277,26 U. S. C. A. (1926) $\$ 960$ note. Cf. Revenue Act of 1932, \$166, 47 STAT. (1932) 221, 26 U. S. C. A. (Supp. 1933) \$3166.

83 (1933) 289 U. S. 172. 
trust might be modified or revoked at any time by an instrument signed by the grantor and either one of the other two trustees. The Commissioner of Internal Revenue ruled that under the statute, as above quoted, the trust income must be returned by the grantor, and consequently an additional tax was assessed against him. The latter contested the validity of this tax on three grounds.

First, it was contended that the statute was being applied retroactively and hence in violation of due process of law, since the trusts had been created prior to the original enactment of the statutory provision in question. The taxpayer relied upon the cases previously referred to herein, which held inheritance and gift taxes to be unconstitutional when retroactively assessed..$^{84}$ But the Supreme Court held that the principle of those decisions had no application to the present case. Here the subject of the tax is not the creation of the trusts or the transfer of the corpus, but, the income of the trusts which accrued after January 1, 1924, the effective date of the Revenue Act of 1924. In other words, for purposes of income taxation, the measure of retroactivity is the date when the income accrues or is received-not the date of creation of the trusts. Even on this basis the statute had had some retroactive effect since it had not been enacted until June 2,1924, but covered income received subsequent to January first of that year. But the Supreme Court had previously held that such limited retroactive effect within the year is unobjectionable in an income tax law, ${ }^{85}$ and the same result was approved here.

Secondly, the settlor argued that as a matter of construction of the statute, the trust income should not be attributed to him under the circumstances presented. The argument on this point hinged on the meaning of the word "beneficiary." 86 The Act declares that the trust income shall be included in computing the net income of the grantor, where the latter has the power to revest title in himself "either alone or in conjunction with any person not a beneficiary of the trust." One of the trustees, the grantor's son, was admittedly a beneficiary. The taxpayer contended that the bank was also-merely because of its status as trustee. The Court very properly held that there was no

84 Nichols v. Coolidge, supra note 64; Untermyer v. Anderson; Blodgett v. Holden, both supra note 68 .

85 Cooper v. United States (1930) 280 U. S. 409. See also Brushaber v. Union Pacific R. R. (1916) 240 U. S. 1.

${ }^{86}$ In section 166 of the Revenue Act of 1932 (supra note 82), which in substance corresponds with section $219(\mathrm{~g})$ of the Revenue Act of 1924, Congress has substituted for the words "any person not a beneficiary of the trust" the phrase "any person not having a substantial adverse interest in the disposition of such part of the corpus or the income therefrom." In certain cases this change of phraseology may lead to different results. See (1933) 33 Cor. L. Rev. 756. 
justification for this construction. A trustee is not per se a beneficiary, and hence since the grantor had power to revoke the trust in conjunction with the bank, the income was taxable to the grantor.

This brings us to the taxpayer's third line of attack, which was that the statute, so construed, was so arbitrary as to deny the due process guaranteed by the Fifth Amendment. According to the argument, the exaction was based, not on the settlor's income or on income from his property, but on that which accrued to other persons from property to which they alone had title. Of course it is true that both the legal and beneficial titles to the property here concerned were in other persons than the settlor. It is also true as a general proposition that the income of one person cannot be taxed to another. ${ }^{87}$ But the question is whether this principle should have apphication so long as there is a power of revocation outstanding.

This question had been before the Supreme Court in simpler form three years earher in Corliss v. Bowers. 88 On that occasion also the issue was whether under the same statutory provision the income from property in trust should be returned by the settlor. But the power of revocation was vested in him alone, instead of in him and another trustee jointly as in Reinecke v. Smith. Under those conditions the Court had no difficulty in upholding the constitutionality of the statute. It felt that taxation should be concerned with actual command over the property taxed, rather than with the refinements of title. And since through the power of revocation the income was subject to the unfettered control of the settlor and he was free to enjoy it at his option, it could be taxed to hin as his income whether he saw fit actually to enjoy it or not.

In Reinecke v. Smith the problem was whether the same result should follow when the settlor could not revoke the trust by himself, but could take such action only in conjunction with a third party. The Court held that this limitation upon his power of control was not sufficient to justify a different result. Congress might with reason declare that the settlor should still be deemed to be in control of the property. In its practical aspects such a revocable trust amounts to no more than an assignment of income..$^{89}$ As the Court states, a contrary decision would make evasion a simple matter. For it would be easy to select

87 This principle was applied with unnecessary strictness in Hoeper v. Tax Comm. of Wisconsin (1931) 284 U. S. 206.

88 (1930) 281 U. S. 376.

${ }^{89}$ It is well established that even an irrevocable assignment of imcome, where the assignor continues to own the corpus, does not immunize bim from taxation upon the income. See Lucas v. Earl (1930) 281 U. S. 111; Burnet v. Leininger (1932) 285 U. S. 136. 
some friend as the co-holder of the power of revocation and so to place large amounts of principal and income accruing therefrom beyond the reach of taxation to the grantor, while he retained to all intents and purposes control of both. Thus the Supreme Court gives one more illustration of its inchination to test the constitutionality of taxes in the light of practical realities, rather than in accordance with theoretical forms. (There are exceptions, it may be noted.)

Congress in its effort to prevent evasion through use of the trust device, was not content with section $219(\mathrm{~g})$ of the Revenue Act of 1924, which has just been under discussion. In section 219(h) of the same Act, ${ }^{90}$ it enacted that under certain circumstances even the income of an irrevocable trust should be included in computing the net income of the settlor. This is so (1) when any part of the trust income may, in the discretion of the grantor, either alone or in conjunction with any person not a beneficiary, be distributed to the grantor or held or accumulated for future distribution to him, or (2) when any part of the income of a trust is or may be applied to the payment of premiums upon policies of insurance on the life of the grantor. This second provision was attacked as unconstitutional in Burnet $v$. Wells.9. The complaining taxpayer was the creator of an irrevocable trust, who had been required by the Commissioner of Internal Revenue to include in his own return the trust income in so far as it had been applied to the maintenance of imsurance on his life. The life insurance policies were payable to beneficiaries other than the insured or his estate, and the circuit court of appeals held that the income applied to the payment of premiums thereon could not be attributed to the settlor without an arbitrary taking of his property in violation of the Fifth Amendment.

This decision was reversed by the Supreme Court. In upholding the statute under these circumstances, the Court in effect ruled that not only need taxation not concern itself with refinements of title, but that from a constitutional point of view it need not necessarily concern itself with the title at all. Here the title both to the corpus of the trust and to the income therefrom was definitely out of the settlor and the property could neither be reclaimed nor controlled by him. Broader considerations must be looked to, in order to save the lawmakers from the charge of having done an arbitrary thing. Such broader support for the legislation was found in the interest which the settlor still had

8043 STAT. (1924) 277,26 U. S. C. A. (1926) $\$ 960$ note. Cf. Revenue Act of $1932, \S 167,47$ STAT. (1932) 221, 26 U. S. C. A. (Supp: 1933) \$3167.

01 (1933) 289 U. S. 670 . See also Du Pont v. Commissioner of Internal Revenue (1933) 289 U. S. 685. 
in his life insurance policies. Even though the latter were payable to other beneficiaries, the insured was a party to the insurance contract and still retained a legal interest therein which under certain conditions could be asserted in court. And from a less technical point of view the policies and the trust together constituted the means adopted by the taxpayer for the protection of his dependents. Insurance for dependents is regarded by many as a pressing social duty, and even if not a duty, it is a common item in the family budget. The average man could not be persuaded that a trust such as this was not a benefit to the person who otherwise would have to pay the premiums if the policies were not to lapse. Income permanently applied by the act of the taxpayer to this purpose is income used for lis benefit in such a sense and to such a degree that there is nothing arbitrary or tyrannical in taxing it as lis.

In uploolding the tax upon this general line of thought, the Supreme Court is certainly leaving legal formulæ far behind, although the result seems justified if judged by the practical considerations which the Court has so often said should be dominant. Obviously the decision is more extreme than that in Reinecke v. Smith, which upheld the statute as applied to revocable trusts. That it is getting close to the line is indicated by the fact that the four more conservative members of the Court dissented from the decision. To the dissenting judges, the case was a bald instance of the taxation of $A$ 's income as the income of $B$.

$B$. Income from Mineral Leases. Another group of cases in the Supreme Court, of quite different character, present some problems arising out of mineral leases. First is Burnet v. Harmel. ${ }^{22}$ There the taxpayer was the owner of oil lands in Texas. He executed oil and gas leases of the lands, in return for bonus payments aggregating $\$ 57,000$ in cash, and stipulated royalties, measured by the production of oil and gas by the lessee. The litigation was over the question of how profit resulting from the bonus payments should be returned. The Commissioner treated the gain as ordinary income to be taxed at the regular rates. The taxpayer, however, contended that the casl received constituted gain from a sale of capital assets, taxable under the capital gains section of the Revenue Act at the fixed rate of $12 \mathrm{r} / 2 \% .{ }^{93}$ The Supreme Court sustained the view of the Commissioner.

If the lease involved lad been an oil and gas lease of the ordinary type, under which the title to the oil and gas passes to the lessee only on severance from the leasehold, it was conceded that this would have

92 (1932) 287 U. S. 103.

23 Revenue Act of 1924, §208, 43 STat. (1924) 262, 26 U. S. C. A. (1926) $\$ 939$ note. See Revenue Act of 1932, \$101, 47 STAT. (1932) 191, 26 U. S. C. A. (Supp. 1933) \$3101. 
been the correct result. It had already been established in a different connection that mining operations in general are to be deemed an income-producing operation, rather than a sale of the land or its mineral content; and that payments by lessees to lessors under mining leases are not $a_{1}$ conversion of capital, as upon a sale of capital assets, but are income to the lessor equivalent to payments of rent. ${ }^{94}$ No reason was evident why the same view should not be taken under the income tax law. But the taxpayer argued that the opposite result should be reached in the present case, because, under Texas law, an oil and gas lease operates immediately upon its execution to pass the title of the oil and gas, in place, to the lessee. Therefore, it was said, the transaction was a sale and the profit resulting from the cash payment should be taxable as gain from the sale of capital assets.

This difference between the oil and gas lease in Texas, which has been characterized by the state courts as a present sale of the minerals in place and the oil and gas lease as it exists in other states, where title passes only on severance froin the land, has been deemed material for other purposes. Thus the immunity from federal income taxation of the lessee of state-owned lands has been held by the Supreme Court to hinge upon this feature of the lease under the state law. ${ }^{95}$ But in Burnet v. Harmel the Court pointed out that the state law was not of the same materiality. Here there is concerned only the meaning and application of a federal statute, and the will of Congress as to how the gains in question shall be taxed is not dependent upon state rules. And seeking the intent of Congress, the Court concluded that the application of the capital gains provision of the Revenue Act did not depend upon the nature of the lease. So far as the statute is concerned, it is immaterial whether title to the oil and gas passes before severance or after.

In reaching this result, the Supreme Court once again neglects technicalities of title in order to decide a tax problem upon the basis of broader considerations. What it regarded as decisive was not the legal differences between the two types of lease, but the fact that the economic consequences to the lessor are the same in each instance. In this connection the Court stressed the fundamental purpose of the capital gains provision-which, of course, was to relieve taxpayers from the excessive burdens resulting from the taxation in the year of realization of capital gains often accruing over long periods of time. This kind of

94 Von. Baumbach v. Sargent Land Co. (1917) 242 U. S. 503; United States v. Biwabik Mining Co. (1918) 247 U. S. 116. See also Stratton's Independence, Ltd., v. Howbert (1913) 231 U. S. 399; Goldfield Consolidated Mines Co. v. Scott (1918) 247 U. S. 126.

95 Cf. Group No. 1 Oil Corp. v. Bass, supra note 32, and Burnet v. Coronado Oil \& Gas Co., supra note 28. 
hardship aimed at by the statutory provision, is not ordinarily produced by the taxation as income of the receipts of the lessor from a mineral lease. And this is as true under one type of lease as under the other. Similarly, there is no reason for treating the bonus or cash payments made to the lessor any differently from royalties measured by actual production.

“. . The payment of an initial bonus alters the character of the transaction no more than an unusually large rental for the first year alters the character of any other lease, and the taxation of the one as ordinary income does not act as a deterrent upon conversion of capital assets, any more than the taxation of the other." 96

The general conclusion reached in Burnet v. Harmel was reaffirmed by the Supreme Court a month later in two additional cases-Murphy Oil Co. v. Burnet $t^{97}$ and Bankers Pocahontas Coal Co. v. Burnet. ${ }^{98}$ The latter involved the taxation of royalties received by the lessor of coal lands in West Virginia under a mimeral lease. Although by West Virginia law, as by Texas law, the title to the mineral content of the Icased land passed to the lessee upon execution of the lease, this characterization of the transaction in the local law did not affect the conclusion that the payments were gross income subject to tax, after such deductions as might be allowed by the Revenue Act.

This reference to deductions suggests a different question which was not raised in Burnet v. Harmel, but which had to be considered in one of the cases just cited-Murphy Oil Co. v. Burnet. Operations under a mineral lease, unlike the activities of the lessee under a lease of realty for ordinary purposes, involve the exhaustion of the mineral wealth of the land. For income tax purposes the lessor must be given credit in one form or another for this gradual destruction of the corpus of his investment. If the royalties received by the lessor were regarded purely as a return of capital, the shrinkage of the physical assets would automatically be taken care of. But the result of Burnet $v$. Harmel is that the royalties may not be considered primarily as a return of capital, but are in the nature of rent. It necessarily follows that the lessor must be allowed credit for the exhaustion of his capital, in the form of deductions for depletion. Murphy Oil Co. v. Burnet presented the problem of how these charges for depletion should be determined. If royalties were to be received by the lessor only at regular intervals and in regular amounts, the difficulty would not be great. But as the case was, the lease stipulated that the lessor should receive a large bonus paynent at the start and thereafter royalties of one-fourth of the oil pro-

${ }^{96}$ Supra note 92, at 105.

97 (1932) 287 U. S. 299.

88 (1932) 287 U. S. 308 . See also Strother v. Burnet (1932) 287 U. S. 314. 
duced by the lessee. The Supreme Court decided in the first place that both the bonus and the subsequent royalties should be subject to a depletion allowance. The question then became one of apportionment. The practice of the Commissioner of Internal Revenue in this regard depended upon whether or not the sum of the bonus and the estimated amount of royalties to be received during the life of the lease should exceed the capital investment of the lessor. In the present case it appeared that the bonus plus the expected royalties would not return more than the lessor's capital. Under these circumstances the Commissioner ruled that the full amount of the imitial bonus payment should be allocated to depletion allowance in the year when it was received. In other words, the Commissioner treated the entire bonus as in effect a return of capital, thus reducing pro tanto the depletion allowable on the royalties to be received in later taxable years. This action was sustained by the Court, which said that the method used resulted in a reasonable allowance for depletion within the meaning of the statute.99

In Palmer v. Bender, ${ }^{100}$ a somewhat different question was presented with respect to the allowance of depletion. The taxpayer was the lessee under an oil and gas lease. In 1921 he transferred his interest to another, in consideration of the payment of an initial cash bonus and of subsequent royalties based upon the oil produced. In 1921 and 1922 the bonus and some further royalties were paid to the taxpayer and were reported by him in his tax returns for those years. The question in dispute was whether he was entitled to a corresponding deduction for depletion. The Commissioner refused to allow sucli a deduction on the theory that the transaction amounted to a sale or assignment of the lease by the lessee, and hence that the latter had retained no interest of a sort which is subject to depletion. The taxpayer on the other hand contended that under the state law any such transfer of an interest in land must be regarded as a lease. From this he concluded that the transfer im question was a sublease, and invoked the rule asserted in Murphy Oil Co. v. Burnet that the lessor of an oil and gas well is entitled to a depletion allowance upon bonus and royalties received from the lessee. The question whether under the state law the

99 In a case where the bonus and expected royalties together are found to exceed the capital investment of the lessor, the Commissioner used a different inethod. Then the amount of the bonus would not be allowed in full as equivalent to a return of capital, but the depletion would be distributed ratably between the bonus and the royalties.

If no estimate of the future royalties could be made with reasonable accuracy, the Court says that the whole of the bonus should be treated, as in the Murphy case, as a return of capital. See supra note 97, at 307 .

100 (1933) 287 U. S. 551. 
transfer was an assignment or a sublease was elaborately argued, but the Court thought the distinction immaterial. Whether or not the taxpayer was entitled to an allowance for depletion depends upon the federal statute, and the Court found nothing therein to indicate that its application was to be controlled or varied by any particular characterization by local law of the interests concerned.

"The language of the statute is broad enough to provide . . . for every case in which the taxpayer has acquired, by investment, any interest in the oil in place, and secures, by any form of legal relationship, income derived from the extraction of the oil, to which he must look for a return of his capital." 101

So whether the lessee became a technical sublessor or not, since he retained a right to share in the oil produced, he retained an economic interest in the oil in place, identical with that of a lessor. Such an interest is depleted by production, and is within the meaning and purpose of the statute permitting the deduction.

Stanley Morrison.

School of Law,

STANTORD UNTVERSITY.

101 Ibid. at $55 \%$. 